\title{
Mistaken Identity: Results and Repercussions / Twin Research Reviews: Ovarian Transplants; Kidney Donation; False Beliefs and Emotion Understanding / In the News: Surfing Twins; Driving Twins / Tribute: Daniel G. Freedman
}

\author{
Nancy L. Segal \\ California State University, United States of America
}

M istaken identity does not just affect identical twins, it can also affect the lives of unrelated individuals. The present article reviews several compelling cases in which confusion by others significantly altered the life circumstances of twins and non-twins. Next, current research on ovarian transplants, kidney donation, false beliefs and emotion understanding are reviewed. The concluding sections survey some unusual twin pairs - and pay tribute to the late Dr. Daniel G. Freedman, known for his landmark studies of fear of strangers in infant twins.

\section{Mistaken Identity: Results and Repercussions}

One of the most compelling stories of mistaken identity does not concern monozygotic (MZ) twins, but it has implications for twin reunions. It concerns two young women, both college students at Taylor University in Indiana, who were sharing a van ride home with their peers. The women were Laura Van Ryn and Whitney Cerak, both blonde and athletically built. The car they were riding in suffered a terrible crash, killing five of the passengers. Laura was brought to a nearby hospital for intensive medical treatment. She was comatose. Laura's family was constantly at her bedside, as were many friends, including her boyfriend whom she planned to marry. However, over the next few weeks, the Van Ryn family came to realize that the girl for whom they had been caring was not their daughter - it was Whitney Cerak. One family suddenly found itself grappling with shocking loss, the other with indescribable joy. This story is told in full in Mistaken Identity, authored by the Van Ryn and Cerak families with writer Mark Tabb (Van Ryn et al., 2008).

These events show that some, but not all, look-alikes are related. Some people may recognize their twinship reluctantly, while others may hope for a relationship that does not exist.

I was reminded of the Van RynCerak story by a recent news story of a reunion between $\mathrm{MZ}$ female rearedapart twins. Their separation resulted from an unintentional switch of one infant by hospital staff. This led to lawsuits (in the order of millions of dollars), filed on behalf of three 35year-old women (Catan, 2008). Two of the women are the separated MZ twins, and the third (unrelated) woman was raised as the dizygotic (DZ) co- twin of one of the twins. A chance meeting between one of the real twins and a store assistant in the Canary Islands unexpectedly revealed the real relationships among the three women.

Seven years ago, upon entering a shop, one of the twins was greeted warmly by the assistant who believed she was her good friend. When the twin did not return the greeting the assistant felt slighted. Later that day, she called her friend to follow up on this unfriendly encounter, but learned that her friend had not visited the mall that day. When the first woman returned to the store several days later the assistant questioned her closely.

Address for correspondence: Nancy L. Segal, Department of Psychology, California State University, Fullerton, CA 92834, USA. E-mail: nsegal@fullerton.edu 
She felt certain that the two were twins. A meeting was arranged and it seemed certain that they (the woman and the friend) were identical twins; DNA testing later confirmed this. It was also disclosed that the woman had a twin sister, but that the two were not identical. Eventually, it was established that one of the twins had been accidentally switched with a nontwin infant in the hospital's baby nursery. It was also revealed that the MZ twins had been conjoined and successfully separated, although the nature of their physical connection was not reported (CityNews, 2008). Everyone's life was significantly altered by that chance meeting between the twin and the assistant.

This case raises difficult questions. Most importantly, did their parents realize they were identical? If they had, they might have recognized the switch when the twins were babies.

This case generated considerable publicity, although the names of the parties have remained confidential. Little is known about how the three women are coping with this news, but some comments are revealing. The twin raised separately in a nonbiological family claimed that, 'In just one day, my world fell apart' (Catan, 2008). Her attorney affirmed this sentiment in his assertion that a child's right to his or her family identity had been 'violated' (CityNews, 2008). It is also known that the nonidentical 'twin' was the biological child of these parents. Therefore, at least two couples suffered the loss of a biological daughter, but the damages do not stop there. Both twins suffered the loss of an identical twin sister, and the nonidentical 'twin' lost her twinship, as well as her presumed biological ties to her parents and any brother and sisters with whom she may have grown up; her emotional ties with her family may not have been affected, but this is unknown.

It is difficult to rank order damages in this case, but compensation in a similar situation may provide clues. I discuss that case in my book, Indivisible by Two, in a chapter entitled, 'Switched at Birth'. A set of Canadian MZ male twins and a third unrelated male infant had been placed in the same temporary foster home. When two of the infants were moved to a second home, the twins did not go with one another, as planned - instead, one twin and the unrelated male were moved together. The twins' biological parents returned to claim their twin sons 2 months later, but unknowingly received one of the twins and the unrelated child. They fully believed that they were raising their own nonidentical twin boys. Their other twin son had been adopted by a different family — so this case does not completely parallel that of the Spanish pair in which the reared apart twin was apparently raised with her presumed biological family. The real Canadian twins eventually met at Carleton University in Ottawa, through mistaken identity, at the age of 20 . They were friends for about a year before it occurred to them that they might be twins.

A lawsuit was brought against the agency that had been responsible for the placement and care of the three boys. The details of the settlement could not be released, but the award structure could. The largest amount was given to the biological parents (who were denied their twin son), with increasingly reduced amounts given to the unrelated son (who was robbed of his identity), the twins (who were denied their twinship), the separated twins' adoptive parents (who raised a child that was not intended for them) and the twins' biological and adoptive siblings (whose relationships with each twin/non-twin were radically revised). This is just one solution. One could argue, as did the adoptive mother, that the adopted twin suffered the most, having felt unwanted all his life, when the opposite was the case. Of course, it is impossible to unequivocally determine who suffered the most and to assign monetary values. It is, however, important to acknowledge the significance of the twin relationship, as this case does. It will be of great interest to learn the outcomes of the Spanish case.

Both of these cases are stunning models for behavioral research. Both yield a separated $M Z$ twin pair and a rare pair of virtual twins (VTs), effectively disentangling genetic and environmental effects. VTs are unrelated siblings reared together from birth, thereby approximating twinship, but without the genetic link (Segal, 2007). They are created when families adopt two same-age children at the same time, or adopt one child shortly before or after having a biological child of their own. Members of the VT pairs created in these switched at birth cases are a unique subset of VTs because they believed that they were DZ twins.

Stories like these may cause some parents to wonder if children whose behavior and/or appearance does not match their own might really belong to other couples. Children in such families may face similar doubts. In most cases, these worries will lack merit, given that newborn babies wear ID tags and novel gene combinations in children may cause them to look and act in unique ways. There are other complications. News of joyous reunions may bring false hopes and disappointments to some couples. I arranged DNA testing for two mothers whose adopted Chinese children bore an unusual physical resemblance to one another - but their daughters were unrelated. This was a difficult conclusion for one mother to accept (Segal, 2006).

No-one knows how many twins are currently searching for one another, or how many people are living lives as the singletons they believe themselves to be. Some of these twins will never meet one another, but we can celebrate (and study) the ones that do. These cases also highlight the crucial roles that twin researchers can play as expert witnesses, affecting the outcomes of legal decisions involving twins and other multiples. 


\section{Twin Research Reviews}

\section{Ovarian Transplants}

The outcomes of ovarian transplants in eight $\mathrm{MZ}$ female twin pairs have been documented by Silber et al. (2008), at the Infertility Center of St. Louis. All patients had undergone transplantation of one ovary donated by their twin sister. Following the operation, all 8 women experienced the onset of their menstrual cycle, although the timing ranged between 7 and 142 days postsurgery. At the time the paper went to press, six recipients had conceived naturally, two babies had been born, one pregnancy had ended in a miscarriage and three pregnancies were in progress.

The authors noted that approximately $1 \%$ of women undergo premature menopause, that is, before 40 years of age. They also noted that previous twin studies have shown genetic effects on menopausal timing, but that a minority of $\mathrm{MZ}$ female twins are discordant for this trait. Reasons for this discordance are speculative. They include late zygotic splitting as a risk factor for interference with germ cell development, epigenetic factors that might affect the follicle supply, and imprinting defects that are more frequent in multiple birth than in single birth pregnancies.

\section{Kidney Donation}

Physicians' attitudes toward organ donation within young sibships have been of interest. A recent study questioned members of the American Society of Transplanation and physicians from the American Academy of Pediatrics (Sections of Nephrology or Bioethics) as to their views on kidney donation between minor $\mathrm{MZ}$ and $\mathrm{DZ}$

\section{In the News}

\section{$\overline{\text { Surfing Twins }}$}

Identical twins, Millis and Michael Wilton, are champion surfers (Abdollah, 2008). They have co-authored five books on the philosophy of surfing, including Discover the Greatness in You. twins (Joseph et al., 2008). Responses were received from 39\% (170/436) of the potential participants.

It was found that $39 \%$ favored kidney donation between 15-year-old MZ twins and 32\% favored kidney donation between 15-year-old DZ twins. These percentages rose to $45 \%$ and $39 \%$, respectively, when the wait time was increased from one to six years. Nevertheless, the majority of respondents did not endorse kidney donation for minor children, even in the case of $\mathrm{MZ}$ twins whose matched immune systems virtually guarantee organ acceptance.

This study, while of interest, was based on hypothetical scenarios presented to professionals, not to twins and families facing real-life decisions. Systematic assessment of MZ and DZ twins' attitudes in actual situations in which organ donation is an option would be clinically and theoretically significant. I raised this issue several years ago in a previous issue of this journal (Segal, 2005a). On the practical side, research findings would help physicians and families manage future cases. On the theoretical side, it would offer tests of hypotheses generated by kinshipgenetic theory, namely that individuals should be more likely to assist close genetic kin than distant genetic kin in life-threatening situations.

\section{False Beliefs and Emotion Understanding}

$\mathrm{MZ}$ and DZ twins progress through the same developmental stages as nontwin children, yet they do so with a same-age sibling. The consequences of being reared as a twin for understanding false beliefs and emotions were examined in $\mathrm{MZ}$ twins and $\mathrm{DZ}$ twins, and in a comparison group of nontwin children, ages 3.9 to 5.1 years of age (Deneault et al., 2008). It was expected that twins, especially $\mathrm{MZ}$ twins, should perform more poorly on the two false belief tasks and three emotion tasks that were administered. The reasoning was that $M Z$ twins develop in close proximity to an identical other, a situation that reduces variation in their social experiences. This was suggested by Peterson's (2000) variety hypothesis, which asserts that exposure to different siblings assists children in understanding the perspectives of others.

Twin groups differences were not found for the false belief tasks, nor did the twins differ from the non-twins. In contrast, the DZ twins and non-twins outperformed the $M Z$ twins on the emotions tasks. It was suggested that MZ twins' close social relationships may interfere with how they understand others' emotions.

This study recalls J.P. Scott's (1977) seminal work with different dog breeds. He manipulated dogs' rearing situations so that some animals were raised with others of the same or different genotype. It was shown that dogs receiving early exposure to different genotypes showed increased cooperation with partners of either the same or different breed in an experimental situation. I was unable to replicate this finding in a twin study comparing joint puzzlesolving behaviors between $\mathrm{MZ}$ and $\mathrm{DZ}$ twins paired with an unfamiliar 'cotwin' (Segal et al., 1996). I concluded that the MZ twins in this study probably had had sufficient experience with individuals outside their twinship that offset any "social dampening" from close contact within the pair.
They have also been featured in film. Unfortunately, Millis was in a serious car accident in early June and is on life support. According to his twin brother, Millis is the record holder for surfing the two largest waves in Hawaii.

\section{$\overline{\text { Driving Twins }}$}

A seemingly ordinary incident in Cambridge, England involving $\mathrm{MZ}$ twins is both theoretically and practically meaningful. Adam and Scott Barker, 17-year-old students, both 
passed their driving test on the same day (BBC News, 2008). They were independently tested by the same examiner. However, both twins received 'minor marks' for stalling at the same set of lights. According to the driving instructor, receiving a minor

\section{Tribute}

\section{Daniel G. Freedman \\ January 16, 1927 - June 10, 2008}

Daniel G. Freedman was a major contributor to research and thinking in child development, behavioral genetics, human ethology and evolutionary psychology. He was a courageous person, unafraid to address controversial topics, such as biological influences on sex differences and cross-cultural variation. He recognized that biological and evolutionary viewpoints were needed to fully understand the diversity of human behavior. These perspectives are becoming increasingly embraced by twin researchers, behavioral geneticists and others.

Dan Freedman had a long and varied career, one that took him to the University of California, Berkeley (BA, 1949), the University of Colorado (MA, 1953), the famed laboratories in Bar Harbor, Maine under John Fuller and J.P. Scott where he collected his dissertation data on four breeds of dogs, and Brandeis University (Ph.D., 1957). He held a U.S. Public Health Service Fellowship at the Langley Porter Neuropsychiatric Institute, in San

\section{References}

Abdollah, T. (2008, June 8). Big-wave surfer hurt in crash; Friend dies. Los Angeles Times, p. B3.

BBC News. (2008, January 24). L-test for identical twins. $B B C$ News. Retrieved from http://news.bbc.co.uk/hi/uk-news/ england/cambridgeshire/4201677.stm

Catan, T. (2008, May 28). Spanish twins separated at birth by mistake are reunited. Times Online. Retrieved from http://www.timesonline.co.uk/tol/ news/world/europe/article4016045. ece. mark is difficult, so it is 'amazing' when two people receive one for the same mistake.

Theoretically, this case is consistent with the psychological literature showing genetic influence on information-processing skills, such as inspection time (Luciano et al., 2001) and on psychomotor skills, including skill acquisition (Fox et al., 1996). This case should also encourage educators from wrongly accusing twins of cheating when they produce similar answers and errors (Segal, 2005b).
Francisco (1957-1959). He received an NIMH Special Fellowship for study at the Institute for Medical Genetics, in Uppsala, Sweden (1963-1964), after which time he joined the Biology faculty at the University of Chicago (1964-1968). Next, he co-led (with Gregory Bateson) an observational study of different cultures, in conjunction with the International School of America (1971-1972). He then rejoined the University of Chicago as a Professor of Human Development (1977-present). During this time he visited the Australian National University, in Canberra (1979), the Hebrew University of Jerusalem (1986), and the Institute for Juvenile Research, in Chicago (1989). He was also associated with the Center for Family Studies, at Chicago's Northwestern University (1985-1986). Most recently, he was a visiting scholar at Nankai University, in Tianjin, China (1995). He is famous for his classic longitudinal study of infant twins in which he demonstrated genetic influences on the fear of strangers and other behaviors (Freedman \& Keller, 1963). He made marvelous use of $16 \mathrm{~mm}$ film, capturing the twins' behaviors in a ter-

CityNews. (2008, May 28). Separated conjoined twins sue for millions after wrong children taken home from hospital. CityNews. Retreived from www. citnews.ca/news_23177aspx.

Denault, J., Picard, M., Decarie, T. G., Morin, P. L., Quintal, G., Boivin, M., Tremblay, R. E., \& Pérusse, D. (2008). False belief and emotion understanding in monozygotic twins, dizygotic twins and non-twin children. Cognition and Emotion, 22, 697-708.

Fox, P. W., Hershberger, S. L., \& Bouchard, T. J., Jr. (1996). Genetic and environ- rific 1963 piece, "Development of the Smile and Fear of Strangers, with an Inquiry into Inheritance of Behavior."

Colleagues organized a festschrift in his honor, at the University of Chicago in October, 1995, funded by the American Psychological Association. This event resulted in a volume, Uniting Psychology and Biology: Integrative Perspectives on Human Development (Segal et al., 1997).

As Professor Emeritus of Psychology at the University of Chicago, Freedman resided in Ribera, New Mexico, where he pursued a number of interests. He was especially concerned with issues of non-duality, especially the unity of biology and culture. He was preparing to read a paper on this subject at the 2008 meeting of the International Society for Human Ethology, in Bologna, Italy, where he was to be honored as one of the founders of the field.

Dr Daniel G. Freedman was my thesis advisor at the University of Chicago. I am part of a close-knit group of his former graduate students who still marvel at what a terrific scholar and friend he was, both in Chicago and beyond. We miss him already.

mental contributions to the acquisition of a motor skill. Nature, 384, 356-358.

Freedman, D. G. (1963). Development of the smile and fear of strangers, with an inquiry into inheritance of behavior. (Available from Pennsylvania State University Audio-Visual Services. University Park, PA, No.22696),

Freedman, D. G., \& Keller, B. (1963). Inheritance of behavior in infants. Science, 140, 196-198.

Joseph, J. W., Thistlewaite, R., Jr., Josephson, M. A., \& Ross, L. F. (2008). 
An empirical investigation of physicians' attitudes toward intrasibling kidney donation by minor twins. Transplanation, 85, 1235-1239.

Luciano, M., Smith, G. A., Wright, M. J., Geffen, G. M., Geffen, L. B., \& Martin, N. G. (2001). On the heritability of inspection time and its covariance with IQ: A twin study. Intelligence, 29, 443-457.

Peterson, C. C., (2000). Kindred spirits. Influences of siblings' perspectives on theory of mind. Cognitive Development, 65, 1228-1238 (cited in Deneault et al., 2008).

Scott, J. P. (1977). Social genetics. Behavior Genetics, 7, 327-346.
Segal, N. L. (2005a). Twin transplants. Twin Research and Human Genetics, 8 538-541.

Segal, N. L. (2005b). Education Issues. Twin Research and Human Genetics, 8, 409-414.

Segal, N. L. (2006). Laboratory findings: Not twin, twins, not twins. Twin Research and Human Genetics, 9, 303-308.

Segal, N. L. (2007). Indivisible by two: Lives of extraordinary twins. Cambridge, MA: Harvard University Press.

Segal, N. L., Connelly, S. L., \& Topoloski, T. D. (1996). Twin children with unfamiliar partners: Genotypic and gender influences on cooperation. Journal of Child Psychology and Psychiatry, 37, 731-735.
Segal, N. L., Weisfeld, G. E., \& Weisfeld, C. C. (Eds.). (1997). Uniting psychology and biology: Integrative perspectives on human development. Washington, D.C.: APA Press.

Silber, S. J., DeRosa, M., Pienda, J., Lenahan, K., Grenia, D., Gorman, K., \& Gosden, R. G. (2008). A series of monozygotic twins discordant for ovarian failure: Ovary transplantation (cortical vesus microvascular) and cryopreservation. Human Reproduction, 23, 1531-1537,

Van Ryn, D., Van Ryn, S., Cerak, N., Cerak, C., Cerak, W., \& Tabb, M. (2008). Mistaken identity. New York: Howard Books. 